\begin{tabular}{ll}
\hline & Jurnal Sains Materi Indonesia \\
Homepage: & $\begin{array}{l}\text { Akreditasi LIPI } \\
\text { No.: 602/AU3/P2MI-LIPI/03/2015 } \\
\text { Tanggal 15 April 2015 } \\
\text { ISSN : 1411-1098 }\end{array}$ \\
\hline
\end{tabular}

\title{
PENENTUAN KANDUNGAN ASBES PADA MATERIAL GASKET MENGGUNAKAN TEKNIK PETROGRAFI SAYATAN TIPIS DAN DIFRAKSI SINAR-X
}

\author{
Firmansyah Sasmita ${ }^{1}$, Aditianto Ramelan ${ }^{1}$ dan Nurcahyo Indro Basuki ${ }^{2}$ \\ ${ }^{1}$ Kelompok Keahlian Ilmu dan Teknik Material FTMD - ITB \\ Jl. Ganesha No. 10, Bandung, 40132 \\ ${ }^{2}$ Kelompok Keahlian Geologi FITB - ITB \\ Jl. Ganesha No. 10, Bandung, 40132 \\ E-mail: ramelan@material.itb.ac.id
}

Diterima: 7 Desember 2016 Diperbaiki: 28 Juli 2017 Disetujui: 4 Agustus 2017

\begin{abstract}
ABSTRAK
PENENTUAN KANDUNGAN ASBES PADA MATERIAL GASKET MENGGUNAKAN TEKNIK PETROGRAFI SAYATAN TIPIS DAN DIFRAKSI SINAR-X. Gasket digunakan sebagai penyumbat statis antara dua komponen stasioner, dalam hal ini flens, dari asembli mekanik yang di dalamnya berisi fluida tertentu. Sebelum regulasi tentang pemakaian asbes diperketat, material gasket umumnya mengandung asbes karena keunikan sifatnya, yaitu tahan panas atau api, insulasi listrik, dan relatif terjangkau biayanya. Regulasi dari Occupational Safety and Health Administration (OSHA) 29 CFR 1910.1001 menjelaskan bahwa Asbestos Containing Material ( $A C M$ ) ialah material apapun yang mengandung asbes lebih dari satu persen. Penentuan kandungan asbes pada material penyusun gasket perlu dilakukan mengingat produk-produk tersebut di periode lampau diduga mengandung asbes lebih dari ambang batas yang dipersyaratkan. Teknik karakterisasi untuk mendeteksi keberadaan asbes tidak banyak dan relatif rumit begitu juga dengan aspek praktisnya. Teknik Petrografi Sayatan Tipis (PST) dan Difraksi Sinar-X (XRD) dipilih karena relatif mudah dan praktis meskipun masih terdapat kekurangan di dalamnya. Sebanyak tiga sampel gasket dan satu sampel sebagai pembanding telah dianalisis dengan menggunakan teknik karakterisasi PST dan XRD. Hasil analisis menunjukkan bahwa satu dari tiga sampel positif mengandung asbes lebih dari $1 \%$ berat bertipe mineral serpentin, yaitu ortokrisotil, berdasarkan karakteristik morfologi hasil pengamatan PST dan pola puncak XRD. Hasil karakteristik dari analisis tersebut mirip dengan sampel pembanding yang mengandung asbes dengan tipe mineral serpentin, yaitu klinokrisotil.
\end{abstract}

Kata kunci: Asbes, Asbestos Containing Material, Gasket, Petrografi Sayatan Tipis, Difraksi Sinar-X.

\begin{abstract}
DETERMINATION OF ASBESTOS CONTENT IN THE GASKET MATERIAL USING THIN SECTION PETROGRAPHY AND X-RAY DIFFRACTION TECHNIQUES. Gaskets are used as static seal or filler between two stationery material surfaces, which in this case are flange gaskets of mechanic assembly that contains certain fluids. Prior to more stringent regulations for asbestos usage, gaskets commonly contained asbestos due to its properties such as heat resistance (refractory) and electricity insulator, and relatively cheap. OSHA (Occupational Safety and Health Administration) regulation i.e.29 CFR 1910.1001 defines that ACM (Asbestos-containing material) means any material containing more than $1 \%$ asbestos. Therefore, determination on the content of asbestos in previously made gaskets was undertaken, since they may contain asbestos more than the regulation. In this observation, the techniques used to detect and characterize asbestos in gasket are Thin Section Petrography (TSP) and X-Ray Diffractometer (XRD) analysis because they are quite effective and easy to carry out. Three gasket samples and one sample as standard of comparison have been analyzed, and the results show that one of the three samples positively contains asbestos more than $1 \mathrm{wt} \%$. Based on morphology characteristic on petrographic observation and peak pattern on XRD spectra, the asbestos is identified as orthochrysotile serpentine. These characteristics are similar to that of standard of comparison sample that contains clinochrysotile serpentine.
\end{abstract}

Keywords: Asbestos, Asbestos-containing material, Gasket, Thin Section Petrography, X-Ray Diffraction 


\section{PENDAHULUAN}

Gasket digunakan sebagai penyumbat statis antara dua komponen stasioner, dalam hal ini flens, dari asembli mekanik yang di dalamnya berisi fluida tertentu [1-3]. Sebelum regulasi tentang pemakaian asbes diperketat, material gasket umumnya mengandung asbes karena keunikan sifatnya, yaitu tahan panas atau api, insulasi listrik, dan terjangkau. Regulasi dari Occupational Safety and Health Administration (OSHA) 29 CFR 1910.1001 menjelaskan bahwa Asbestos Containing Material (ACM) ialah material apapun yang mengandung asbes lebih dari satu persen [4].

Penentuan kandungan asbes pada material penyusun gasket perlu dilakukan mengingat produk tersebut yang dipasang sebelum Tahun 1981 diduga mengandung asbes lebih dari ambang batas yang dipersyaratkan [5]. Hal ini dipertegas dengan keluarnya Peraturan Pemerintah (PP) No. 101 Tahun 2014 yang menyatakan bahwa limbah dari gasket mengandung sisa asbes dan termasuk ke dalam Bahan Berbahaya dan Beracun (B3) Kategori 1 dari sumber spesifik umum [6]. Beberapa produk pada rumah tangga, alat transportasi, dan bahan bangunan masih ada yang mengandung asbes [7-10].

Asbes merupakan istilah kumpulan yang mengacu kepada sejumlah mineral silikat terhidrasi dimana bentuk kristalnya panjang, kuat dan berserat fleksibel yang dapat dipisahkan menjadi sekumpulan serat-serat halus. Ciri penting asbes dibandingkan dengan jenis mineral silikat non abses ialah keberadaan serat-serat yang mudah dipisahkan. Enam tipe asbes yang umum termasuk ke dalam kelompok mineral serpentin (serpentine) atau pun amfibol (amphibole). Tipe yang termasuk serpentin adalah krisotil (chrysotile) sedangkan amfibol terdiri dari amosit (amosite), antofilit (anthophyllite), krokidolit (crocidolite), tremolit (tremolite), dan aktinolit (actinolite) [11]. Tipe kelompok serpentin yang lain ialah antigorit (antigorite) dan lizardit (lizardite)yang diklasifikasikan sebagai non asbes karena bukan berbentuk serat [12].

Tidak banyak literatur yang membahas tentang penentuan kandungan asbes terutama pada gasket. Teknik yang dapat digunakan untuk menganalisis kandungan asbes pada material ruah atau bulk, yaitu Mikroskop Stereo, Gravimetri, Mikroskop Polarisasi atau Polarized Light Microscopy (PLM), $X$-Ray Diffraction (XRD), dan Mikroskop Elektron [1315]. Pemanfaatan alat mikroskop polarisasi untuk menganalisis batuan atau mineral lazim disebut dengan Petrografi Sayatan Tipis. Teknik Petrografi Sayatan Tipis (PST) dan XRD dipilih untuk menentukan kandungan asbes pada material gasket karena relatif mudah dan praktis meskipun masih terdapat kekurangan di dalamnya.

\section{METODE PERCOBAAN}

\section{Bahan dan Alat}

Sampel-sampel gasket yang dianalisis sebanyak tiga (3) buah yang diambil dari sambungan flens pada instalasi pipa minyak dan gas yang sudah tertanam selama lebih dari 20 tahun. Sebagai pembanding, satu (1) sampel standar yang sudah mengandung asbes lebih dari $1 \%$ berat juga dianalisis.

Analisis terhadap sampel-sampel gasket dan standar dilakukan dengan Teknik Petrografi Sayatan Tipis menggunakan Nikon Eclipse 50i POL Polarizing Microscope dan Difraksi Sinar-X menggunakan Philips Analytical PW1710 Based X-Ray Diffractometer.

\section{Cara Kerja}

\section{Penyiapan Sampel}

Sampel-sampel gasket diberi label sebagai berikut; "G-1", "G-2", dan "G-3" sedangkan sampel standar berlabel "Std".

\section{Petrografi Sayatan Tipis}

Sampel-sampel gasket maupun standar ACM dipreparasi menjadi sayatan tipis dengan ketebalan standar $\pm 30 \mu \mathrm{m}$ dan direkatkan ke glass slide dan glass cover menggunakan epoxy (indeks bias: 1,54). Sayatan tipis tersebut dianalisis dengan menggunakan Mikroskop Polarisasi Nikon Eclipse 50i POL menggunakan lensa polarisator bawah (pengamatan nikol sejajar) dan polarisator atas/analisator (pengamatan nikol bersilang).

Untuk mengidentifikasi mineral, maka karakter mineral yang diamati dalam pengamatan nikol sejajar meliputi bentuk mineral, belahan (cleavage), warna, perubahan warna (jika ada), relief (yaitu perbedaan harga indeks bias mineral terhadap epoxy; semakin besar perbedaan tersebut maka semakin tinggi kenampakan reliefnya). Pengamatan karakter mineral pada nikol bersilang meliputi warna bias rangkap (yaitu warna hasil interferensi gelombang saat melewati mineral), orde (atau intensitas) warna bias rangkap, dan tipe pemadamannya (kondisi ketika mineral tampak gelap maksimum). Pengamatan warna bias rangkap dan ordenya menggunakan acuan Michel-Levy Interference Color Chart [16]. Analisis sayatan tipis umumnya dilakukan tanpa menggunakan compensator plate (gypsum plate). Penentuan kelimpahan mineral yang dijumpai dalam sayatan tipis sampel gasket menggunakan cara semi kuantitatif yaitu estimasi visual mempergunakan referensi chart standar [17].

\section{X-Ray Diffraction}

Sebanyak kurang lebih 5 gram dari masing-masing sampel gasket maupun standar dibuat menjadi serbuk 
Penentuan Kandungan Asbes pada Material Gasket Menggunakan Teknik Petrografi Sayatan Tipis dan Difraksi Sinar-X (Firmansyah Sasmita)

untuk dikarakterisasi $X R D$ menggunakan Philips Analytical PW1710 Based X-Ray Diffractometer ( $\mathrm{CuK}_{\mathfrak{a}}$, tegangan $=40 \mathrm{kV}$, arus $=30 \mathrm{~mA}$ ). Sampel dipindai secara kontinyu pada rentang sudut $2 \theta$ mulai dari $5^{\circ}$ hingga $65^{\circ}$. Analisis kualitatif dibantu dengan perangkat lunak PC-APD versi 3.6g, yaitu dengan membandingkan pola puncak difraksi sampel dengan standar yang dikeluarkan oleh International Center for Diffraction Data (ICDD) berjenis Powder Diffraction File (PDF)-2. Hasil analisis kuantitatif dibantu dengan perangkat lunak XPowder Ver. 2004.04.46 Pro berdasarkan metode Normalized Reference Intensity Ratio (RIR).

\section{HASIL DAN PEMBAHASAN}

Morfologi hasil analisis dengan PST dari sampel G-1 ditunjukkan pada Gambar 1. Hasil analisis kualitatif menunjukkan bahwa sampel ini tersusun oleh serpentin, serabut halus karbonat/opak dan sedikit tremolit, yang dikelilingi oleh matriks dengan pewarna hijau.
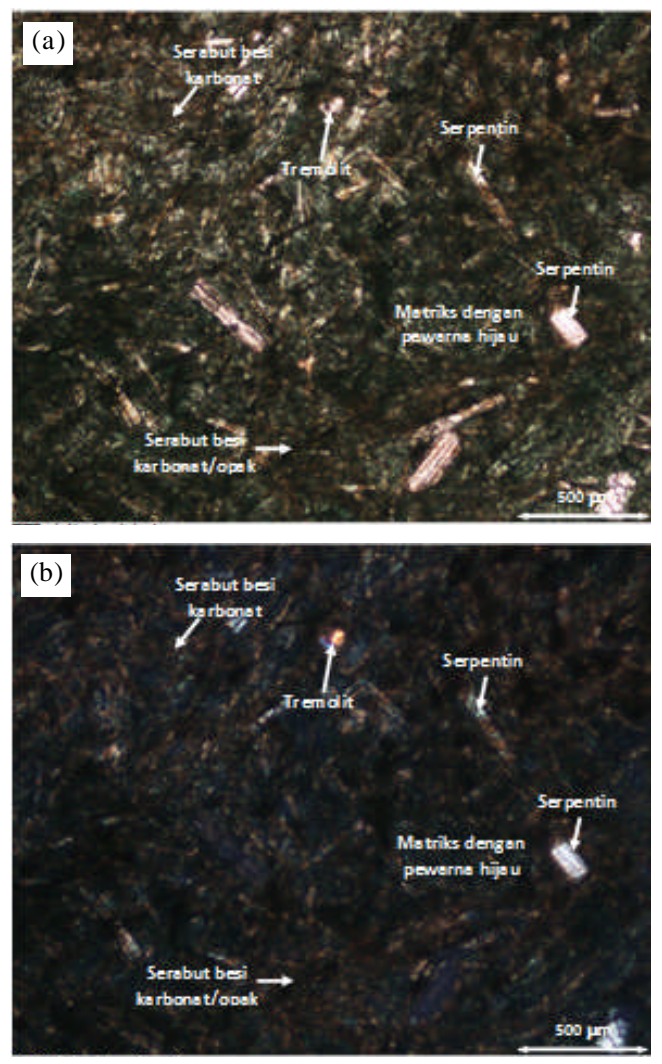

Gambar 1. Morfologi sampel G-1 (a). PPL (nikol sejajar) dan (b). XPL (nikol bersilang).

Fasa karbonat (diduga siderit; 25\%) dijumpai berupa serabut-serabut halus memanjang yang tersebar secara acak dan tidak menunjukkan orientasi tertentu (random). Serabut karbonat berwarna coklat gelap dengan warna bias rangkap ekstrim, yang kemungkinan mempunyai kadar besi tinggi. Serabut karbonat seringkali mendekati sifat opak (coklat hitam). Serpentin (12\%) dijumpai berupa bilah-bilah atau prismatik (prismatic) dengan bentuk euhedral dan belahan (cleavage) yang jelas. Serpentin dalam sampel ini mempunyai relief yang relatif lebih tinggi dibandingkan dengan di dalam sampel lainnya. Tremolit (trace atau ikutan, $<<1 \%$ ) hadir setempat berukuran sangat halus (mencapai $0,2 \mathrm{~mm}$ ) dengan ciri relief medium, tidak berwarna (colorless) dan bias rangkap (birefringence) berwarna kuning orde-2. Matriks (62\%) tersusun oleh materialyang tidak teridentifikasi dengan pencampur bahan pewarna hijau yang tersebar dalam sampel.

Gambar tersebut menunjukkan adanya kristal tremolit berukuran sangat halus tampak di bagian tengah atas dengan warna bias rangkap kuning orde-2. Bentuk kristal, relief dan belahan serpentin dalam sampel ini mirip dengan antofilit, namun karena warna bias rangkap yang rendah (abu-abu orde-1) maka diinterpretasikan secara umum sebagai serpentin.

Gambar 2 menunjukkan morfologi pada sampel G-2. Terlihat bahwa sampel gasket ini tersusun oleh lembaran dan serabut halus serpentin, kuarsa dan sedikit material opak berukuran halus, yang dikelilingi oleh matriks material lempung (warna coklat tua) yang melimpah dan sedikit karbonat (kalsit).
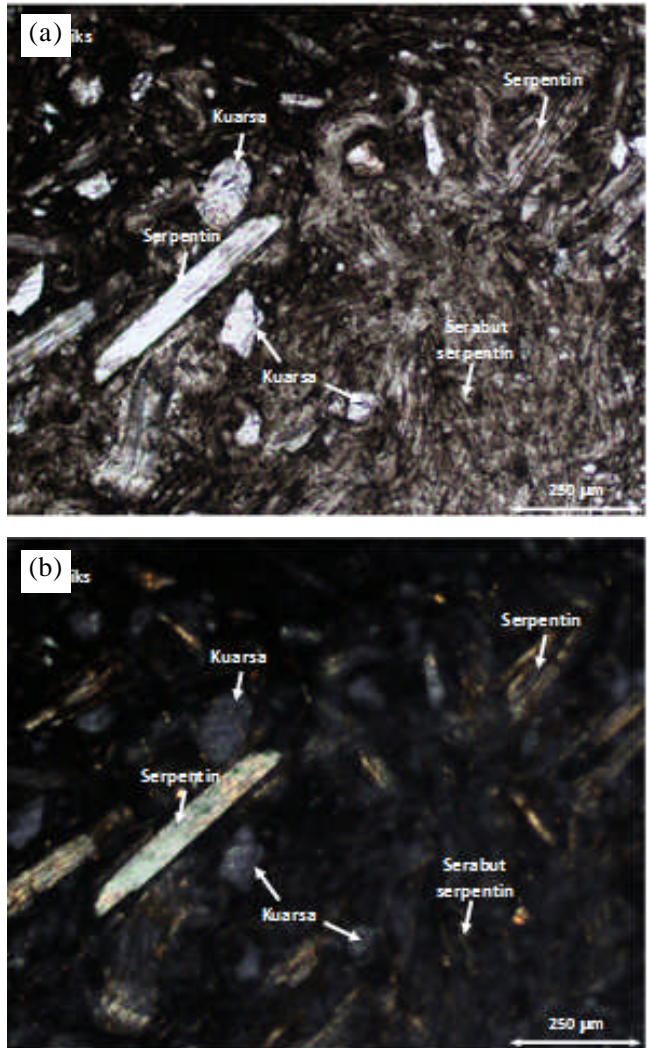

Gambar 2. Morfologi sampel G-2 (a). PPL (nikol sejajar) dan (b). XPL (nikol bersilang).

Fasa serpentin (45\%) dijumpai berupa bilah-bilah (prismatik) atau lembaran dengan bentuk euhedral dan belahan yang jelas, dan juga berupa serabut-serabut halus memanjang. Serpentin tersebar secara acak dan tidak menunjukkan orientasi tertentu. Serabut serpentin 
seringkali menunjukkan gejala deformasi, yaitu berbentuk melengkung (bent), kemungkinan akibat preparasi sampel. Serpentin terubah setempat oleh bercak halus kalsit, terutama di bagian tepi mineral atau pada bagian belahannya.

Material opak kadang dijumpai sebagai inklusi halus dalam serpentin ataupun tumbuh mengikuti belahan serpentin. Kuarsa (10\%) hadir berupa butiran berukuran pasir halus hingga kasar (sekitar 0,1 hingga $0,3 \mathrm{~mm}$ ), berbentuk tak beraturan menyudut, terdiri dari kuarsa monokristalin. Material opak (1\%) hadir sebagai bercak-bercak halus $(<30 \mu \mathrm{m})$ yang tersebar di dalam matriks. Matriks (43\%) terdiri dari material berwarna coklat tua hingga hampir opak (material berukuran lempung). Di beberapa tempat dijumpai bercak halus kalsit $(<1 \%$; umumnya $<10 \mu \mathrm{m}$ ). Jika diamati lebih lanjut, serabut dan bilah halus serpentin tampak tersebar tanpa memperlihatkan orientasi kristal, dikelilingi oleh matriks berwarna coklat tua. Beberapa serabut serpentin tampak terubah sebagian oleh bercak halus kalsit. bentuk kristal, relief dan belahan beberapa serpentin dalam sampel ini mirip dengan antofilit, namun karena warna bias rangkap yang rendah (orde-1) maka diinterpretasikan secara umum sebagai serpentin.

Morfologi dari sampel G-3 ditunjukkan oleh Gambar 3. Hasil pengamatan menunjukkan bahwa spesimen ini didominasi oleh material opak (99\%) dengan sedikit mineral bersifat transparan berjenis kuarsa $(<1 \%)$. Kuarsa berukuran halus mencapai
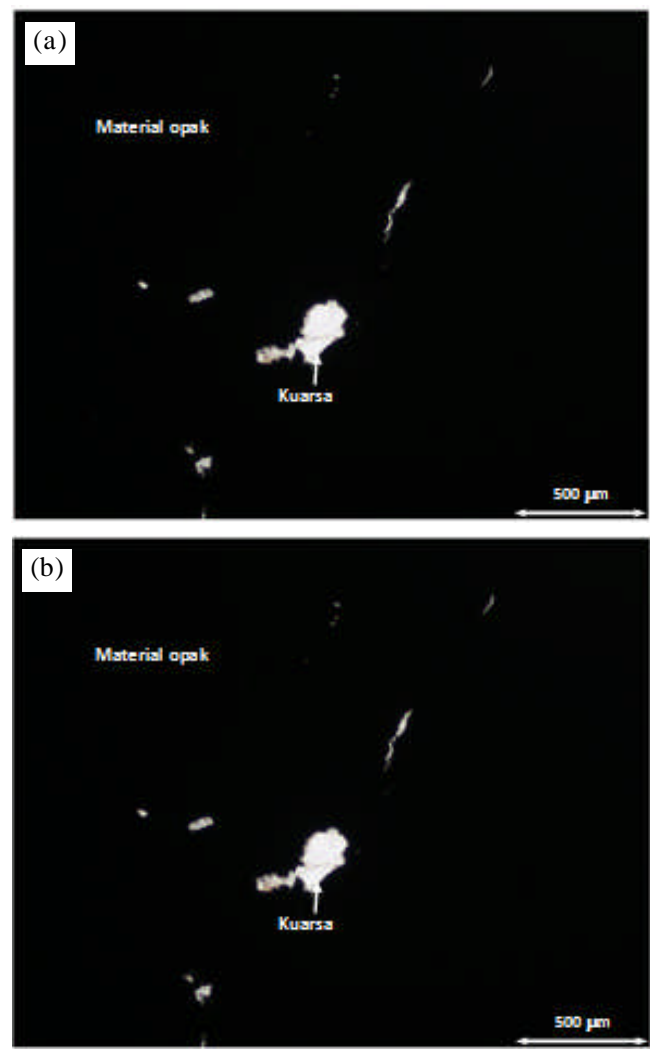

Gambar 3. Morfologi sampel G-3 (a). PPL (nikol sejajar) dan (b). XPL (nikol bersilang).
0,2 $\mathrm{mm}$, berbentuk menyudut dan hanya dijumpai setempat sebagai inklusi dalam material opak. Pemadaman bergelombang (undulatory extinction) terlihat pada beberapa kristal kuarsa. Tidak dijumpai mineral asbes dalam sampel ini.

Sebagai pembanding, sampel Std juga dianalisis menggunakan teknik PST dimana morfologinya dapat dilihat pada Gambar 4. Sampel ini tersusun oleh serabutserabut halus serpentin dan sedikit butiran kuarsa yang tersebar dalam matriks karbonat (kalsit) yang melimpah. Serpentin (total 15\%) dijumpai berupa serabut halus dan lembaran yang tersebar secara acak dan tidak menunjukkan orientasi tertentu. Serpentin setempat menunjukkan ubahan oleh kalsit, terutama di bagian tepi mineral atau pada bagian belahannya. Material opak kadang dijumpai sebagai inklusi halus dalam serpentin ataupun tumbuh mengikuti belahan dalam serpentin. Kuarsa (4\%) hadir berupa butiran berukuran pasir halus hingga kasar (sekitar 0,1 hingga 0,7 mm), berbentuk tak beraturan menyudut, terdiri dari kuarsa monokristalin yang setempat menunjukkan gejala pemadaman bergelombang.
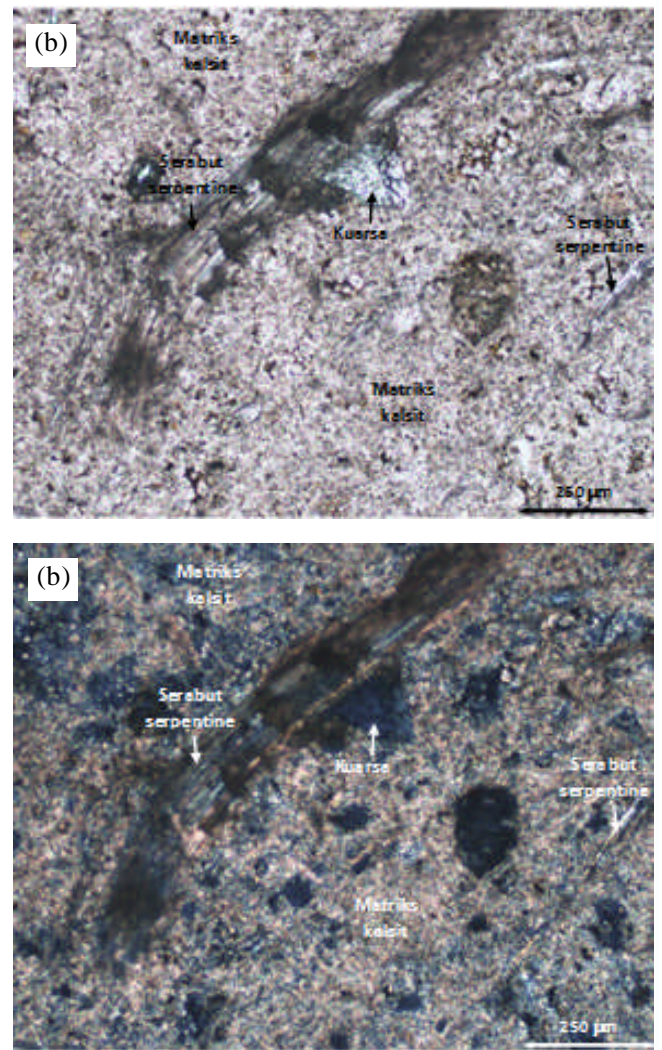

Gambar 4. Morfologi sampel Std (a). PPL (nikol sejajar) dan (b). XPL (nikol bersilang).

Material opak (1\%) hadir sebagai bercak-bercak halus $(<20 \mu \mathrm{m})$ yang tersebar di dalam matriks kalsit, dan sebagai inklusi/tumbuh dalam serpentin. Matriks kalsit (80\%) merupakan fasa penyusun utama sampel ini, berukuran kristal sangat halus (umumnya $<10 \mu \mathrm{m}$ ) dan berwarna coklat keruh. 
Penentuan Kandungan Asbes pada Material Gasket Menggunakan Teknik Petrografi Sayatan Tipis dan Difraksi Sinar-X (Firmansyah Sasmita)

Berdasarkan analisis menggunakan teknik PST, terdapat dua (2) sampel, yaitu G-1 dan G-2 yang diduga kuat mengandung asbes bertipe serpentin. Fasa amfibol (i.e. tremolit) diduga kuat juga terkandung di dalam sampel G-1. Jika dibandingkan dengan sampel Std, serpentin dalam kedua sampel gasket tersebut ada yang berbentuk bilah-bilah (atau lembaran berbentuk euhedral) dan atau serabut. Serpentin dengan bentuk serabut hanya ditemukan dalam sampel Std.

Untuk mengkonfirmasi keberadaan asbes berdasarkan hasil analisis menggunakan PST, Teknik $X R D$ juga dilakukan mengingat kelebihannya dalam mengidentifikasi keberadaan fasa-fasa atau senyawa berdasarkan karakteristik struktur kristalnya.

Rangkuman hasil analisis kualitatif keempat sampel dengan menggunakan Teknik XRD dapat dilihat pada Tabel 1. Hasil analisis kualitatif $X R D$ menunjukkan bahwa hanya sampel G-2 dan Std yang positif mengandung asbes bertipe krisotil. Ortokrisotil (orthochrysotile) teridentifikasi pada sampel G-2 sedangkan klinokrisotil (clinochrysotile) pada Std.

Tabel 1. Hasil perbandingan analisis PST dan XRD

\begin{tabular}{|c|c|c|c|c|}
\hline \multirow{2}{*}{ Label } & \multicolumn{2}{|l|}{ PST } & \multicolumn{2}{|l|}{$X R D$} \\
\hline & Senywa/Fasa & $(\mathrm{w} / \mathrm{o})$ & Senyawa/Fasa & $\left({ }^{w} / 0\right)$ \\
\hline \multirow[t]{7}{*}{ G-1 } & Karbonat & 25 & Magnesite, syn & $3,5 \pm 0,7$ \\
\hline & Serpentin & 12 & Antigorite $6 M$ & $35,3 \pm 2,1$ \\
\hline & Tremolit (ikutan) & $<<1$ & $\begin{array}{l}\text { Magnesium Aluminum } \\
\text { Hydrate }\end{array}$ & $25,6 \pm 4,6$ \\
\hline & Matriks & 62 & Illite-2M1 & $15,3 \pm 1,0$ \\
\hline & & & Quartz, syn & $6,4 \pm 1,1$ \\
\hline & & & Kaolinite-1A & $11,4 \pm 0,9$ \\
\hline & & & (Koreksi) Fasa Amorf & 2,5 \\
\hline \multirow[t]{5}{*}{ G-2 } & Serpentin & 45 & Orthochrysotile-6Oc1 & $84,1 \pm 7,7$ \\
\hline & Kuarsa & 10 & Quartz, syn & $1,9 \pm 0,7$ \\
\hline & Opak & 1 & Pyrophyllite- $2 M$ & $6,4 \pm 0,7$ \\
\hline & Kalsit & $<1$ & (Koreksi) Fasa Amorf & 7,6 \\
\hline & Matriks & 43 & & \\
\hline \multirow[t]{4}{*}{ G-3 } & Opak & 99 & Iron Nickel & $94,5 \pm 8,1$ \\
\hline & Kuarsa & $<1$ & Hematite, syn & $0,8 \pm 0,8$ \\
\hline & & & Graphite- $3 R$, syn [NR] & $1,8 \pm 0,8$ \\
\hline & & & (Koreksi) Fasa Amorf & 2,9 \\
\hline Std- & Serpentin & 15 & Clinochrysotile-2Mc1 & $21,3 \pm 0,8$ \\
\hline \multirow[t]{3}{*}{$\mathrm{ACM}$} & Matriks (Kalsit) & 80 & Calcite, syn & $64,5 \pm 7,4$ \\
\hline & Kuarsa & 4 & (Koreksi) Fasa Amorf & 14,2 \\
\hline & Opak & 1 & & \\
\hline
\end{tabular}

Ortokrisotil dan klinokrisotil merupakan politipe (polytype) dari krisotil dimana umumnya klinokrisotil banyak ditemukan di alam sebagai representasi dari krisotil [18]. Sampel G-1 dan G-3 tidak ditemukan indikasi adanya serpentin, hasil analisis $X R D$ ini bersesuaian dengan hasil yang diperoleh dengan teknik PST.

Gambar 5 menunjukkan kurva hasil analisis $X R D$ dari sampel G-1, G-2, G-3, dan Std. Terlihat bahwa kurva $X R D$ untuk sampel G-3 positif tidak mengandung asbes serta hasil analisis PST menunjukkan hal yang sama. Menurut [10,11, 13, 19-21], pola puncak difraksi karakteristik dari krisotil berada pada sudut $2 \theta$ sebesar $12,08^{\circ}$ dan $24,38^{\circ}$ atau $d$-spacing sebesar $7,32 \AA$ (1) dan $3,65 \AA(0,7)$. Kurva $X R D$ di atas menunjukkan bahwa pola puncak difraksi dari sampel

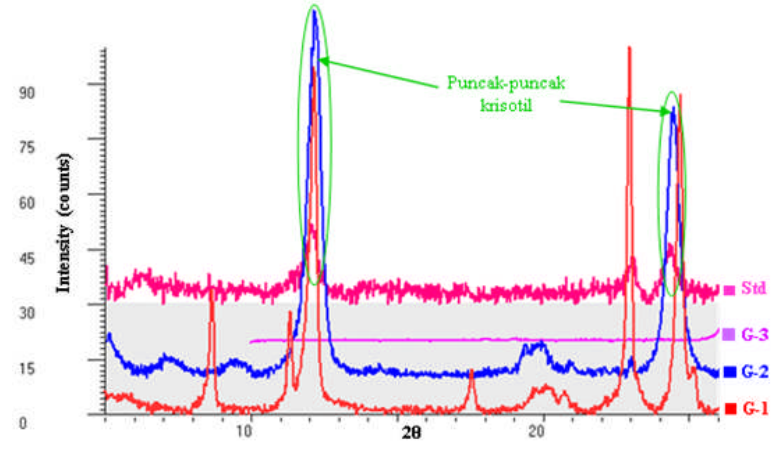

Gambar 5. Difraktogram Sinar-X sampel G-1, G-2, G-3 dan Std pada rentang sudut $2 \theta$ antara $5^{\circ}$ hingga $26^{\circ}$.

G-2 dan $S t d$ berada pada sudut $2 \theta$ atau $d$-spacing yang sesuai dengan literatur yang disebutkan sebelumnya. Hasil $X R D$ tersebut mengkonfirmasi keberadaan asbes bertipe mineral serpentin, yaitu krisotil yang ada di dalam sampel G-2.

Pada sampel G-1, terdapat satu pola puncak difraksi yang berinterferensi dengan sampel G-2 dan Std, yaitu di sekitar sudut $12,08^{\circ} 2 \theta$ atau $d$-spacing sebesar 7,32 A. Pola puncak difraksi tersebut dapat diidentifikasi sebagai krisotil ataupun antigorit karena posisinya sangat berdekatan dan berinterferensi satu sama lain [13,21-23]. Terdapat satu pola puncak difraksi lain yang dapat digunakan untuk membedakan karakteristik antara kristotil dan antigorit, yaitu keberadaan pola puncak pada sudut $41,45^{\circ} 2 \theta$ atau $d$-spacing sebesar 2,17 $\AA$ [23]. Gambar 6 di atas mengkonfirmasi keberadaan antigorit pada sampel G-1 dimana pola puncak difraksi yang dimaksud tidak terdapat pada sampel G-2 dan Std.

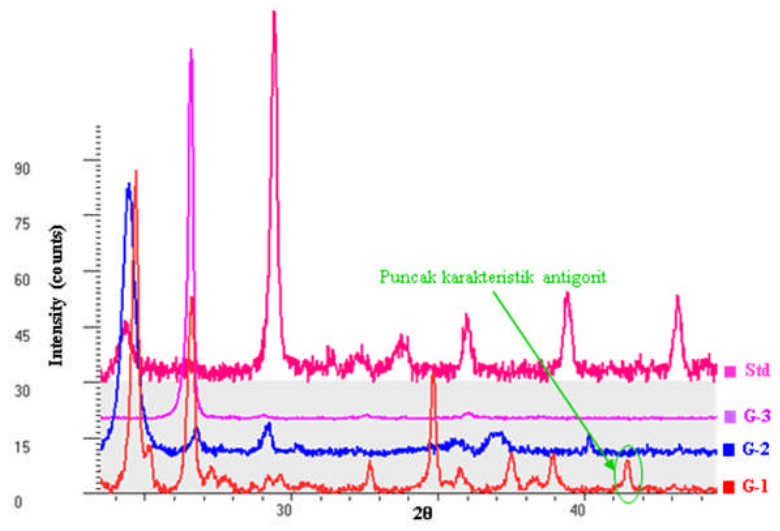

Gambar 6. Difraktogram Sinar-X sampel G-1, G-2, dan Std-ACM pada rentang sudut $2 \theta$ antara $24^{\circ}$ hingga $44^{\circ}$

Hasil analisis sampel G-1 dengan PST, menunjukkan bahwa fasa yang teridentifikasi adalah serpentin namun belum jelas apakah termasuk tipe krisotil atau antigorit. Hasil XRD menunjukkan bahwa sampel G-1 positif mengandung antigorit (mineral serpentin non asbes) karena bentuknya tidak berserat namun berbentuk bilah-bilah ataupun platy.

Hasil perbandingan analisis kualitatif dan kuantitatif antara teknik PST dan XRD dirangkum juga 
dalam Tabel 1 sebelumnya. Hasil analisis kualitatif dengan PST akan dikonfirmasi keberadaan fasa-fasa atau senyawa yang diperolehnya dengan teknik XRD. Sebagai contoh, fasa karbonat (yang diduga sebagai siderit atau $\mathrm{FeCO}_{3}$ ) yang terdeteksi oleh teknik PST pada sampel G-1, terkonfirmasi keberadaannya sebagai magnesit (magnesite) atau magnesium karbonat $\left(\mathrm{MgCO}_{3}\right)$ oleh $X R D$. Begitu juga halnya dengan fasa serpentin akan terdeteksi sebagai antigorit, ortokrisotil ataupun klinokrisotil oleh metode XRD. Meskipun demikian, beberapa fasa dengan jumlah yang relatif kecil ataupun sebagai ikutan tidak bisa terdeteksi keberadaannya secara akurat dengan metode $X R D$. Menurut [13], batas yang masih memungkinkan untuk mendeteksi keberadaan asbes dengan teknik XRD adalah sebesar $1 \%$ berat.

Tabel 1 di atas menunjukkan juga bahwa terdapat perbedaan signifikan pada hasil analisis kuantitatif antara teknik PST dan XRD khususnya pada sampel yang mengandung asbes, yaitu sampel G-1, G-2, dan Std. Sebaliknya, sampel G-3 tidak menunjukkan perbedaan signifikan. Perbedaan tersebut dapat terjadi karena keterbatasan jumlah sampel yang dianalisis kurang dapat mewakili karakteristik yang sesungguhnya, preparasi sampel yang dapat mengubah morfologi serat asbes serta adanya interferensi oleh fasa atau senyawa matriksnya [13].

Berdasarkan aspek praktisnya, metode PST lazimnya digunakan sebagai teknik karakterisasi awal untuk mengidentifikasi keberadaan asbes pada suatu produk berdasarkan karakteristik morfologi dan sifat optik kristalnya sedangkan XRD sebagai teknik karakterisasi lanjutan untuk mengkonfirmasi keberadaan asbes berupa identifikasi sekaligus kuantifikasi senyawa atau fasa yang terkandung di dalamnya dengan batas deteksi asbes minimum adalah $1 \%$ [13]. Khusus asbes bertipe krisotil, batas deteksi minimum adalah sebesar $6 \%$ berat [24]. Namun berdasarkan pengalaman praktis, keterbatasan metode $X R D$ yang dipergunakan adalah tidak mampu mendeteksi secara akurat keberadaan fasa atau senyawa dengan kandungan kurang dari $3 \%$ berat hingga $4 \%$ berat [25].

\section{KESIMPULAN}

Hasil analisis terkait penentuan kandungan asbes pada material gasket dengan Teknik PST dan XRD menunjukkan bahwa satu dari tiga sampel positif mengandung asbes lebih dari $1 \%$ berat dengan tipe mineral serpentin khususnya ortokrisotil. Hasil ini mirip dengan asbes bertipe mineral serpentin, yaitu klinokrisotil, yang terkandung di dalam sampel standar sebagai pembanding. Terkait dengan keterbatasan alat $X R D$ yang dipergunakan maka terhadap kedua sampel lainnya masih perlu dilakukan pemeriksaan lebih lanjut untuk memastikan keberadaan asbes.

\section{DAFTAR ACUAN}

[1]. ESA Publication No. 014/05. Sealing Technology BAT Guidance Notes. UK, 2005.

[2]. R. Flitney. Seals and Sealing Handbook. UK: Butterworth Heinemann, pp. 520, 2007.

[3]. M. M. P. Dan and L. A. Yu. "Design and Analysis a New Materials of Gasket Pipping Using Waste Rubber Tyres and Coconut Coir Fibre." Journal of Advanced Manufacturing Technology, vol. 6, no. 2, pp. 11-27, July-December 2012.

[4]. OSHA Standard 29 CFR 1910.1001. "Asbestos." Washington, DC, 2014.

[5]. OSHA U.S. Department of Labor. "Asbestos." Internet: https://www.osha.gov/Publications/ OSHA3507. pdf, Jan. 2014 [May 3, 2016].

[6]. Peraturan Pemerintah RI No. 101 Tahun 2014. "Pengelolaan Limbah Bahan Berbahaya dan Beracun.” 17 Oktober 2014. Lembaran Negara Republik Indonesia Tahun 2014 Nomor 333, Jakarta.

[7]. S. H. Hwang and W. M. Park. "Evaluation of Asbestos-Containing Products and Released Fibers in Home Appliances." Journal of the Air \& Waste Management Association, vol. 66, no. 9, pp. 922-929, Sep. 2016.

[8]. F. W. Boelter, J. D. Persky, D. M. Podraza and W. H. Bullock. "Characterizing and Communicating Risk with Exposure Reconstruction and Bayesian Analysis: Historical Locomotive Maintenance/ Repair Associated with Asbestos Woven Tape Pipe Lagging." Risk Analysis, vol. 36, no. 2, pp. 228-243, 2016.

[9]. B. L. Finley, J. S. Pierce, A. D Phelka, R. E. Adams, D. J. Paustenbach, K. A. Thuett and C. A. Barlow. "Evaluation of Tremolite Asbestos Exposures Associated with the Use of Commercial Products." Critical Reviews in Toxicology, vol. 42, no. 2, pp. 119-146, 2012.

[10]. J. Y. Hwang, H. M. Lee, J. H. Oh and G. N. Park. "Asbestos Determination of Some Domestic Building Materials Using X-Ray Diffraction." Journal of the Mineralogical Society of Korea, vol. 24, no. 2, pp. 119-131, June 2011.

[11]. G. S. Rajhans and J. L. Sullivan. "Asbestos Sampling and Analysis." Ann Arbor Science Publisher, Inc. 1981.

[12]. R. L. Virta. “Asbestos: Geology, Mineralogy, Mining, and Uses". Internet: http://pubs.usgs.gov/ of/2002/of02-149/of02-149.pdf, 2002 [July 28, 2016]

[13]. R. L. Perkins and B. W. Harvey. "Method for the Determination of Asbestos in Bulk Building Materials.” EPA Test Method. USA. July 1993.

[14]. J. R. Milletteand R. S. Brown. "Environmental Forensic Microscopy." in Introduction to Environmental Forensics, $3^{\text {rd }}$ Ed., B. Murphy and R. Morrison, Ed. New York, Academic Press, pp. 487-511, 2014. 
Penentuan Kandungan Asbes pada Material Gasket Menggunakan Teknik Petrografi Sayatan Tipis dan Difraksi Sinar-X (Firmansyah Sasmita)

[15]. J. R. Millette. “Asbestos Analysis Methods”. in Asbestos: Risk Assessment, Epidemiology, and Health Effects, $2^{\text {nd }}$ Ed., R. F. Dodson and S. P. Hammar, Boca Raton, CRC Press, pp. 23-48, 2012.

[16]. W.S. Mackenzie and C. Guilford. "Atlas of RockForming Minerals in Thin Section." New York, Routledge, pp. 98, 1980.

[17]. R.L. Folk. "A Comparison Chart for Visual Percentage Estimation." Journal of Sedimentary Petrology, vol. 21, no. 1, pp. 32 -33, Mar. 1951.

[18]. Excalibur Mineral Company. "Chrysotile". Internet: h t t p://www.webmineral.com/dat a / Chrysotile.shtml\#.V_X0CyT-5GU, 2016 [August 10, 2016].

[19]. NIOSH U.S. Department of Health \& Human Services. "Asbestos Chrysotile by XRD: Method 9000, vol. 3.” Internet: https://www.cdc.gov/niosh/ docs/2014-151/pdfs/methods/9000.pdf, October 20, 2015 [September 9, 2016].

[20]. F. Hu, N. Gong, L. Zhang, Y. Lu, P. Zhang, X. Xiao and L. Liao. "Quantitative Analysis of Trace Level Asbestos in Pharmaceutical Talc by Powder X-Ray Diffraction." Analytical Methods, vol. 6, pp. 1862-1867, Mar. 2014.
[21]. S. Hashimoto, H. Takeda, A. Okuda, A. Kambayashi, S. Honda, Y. Iwamoto and K. Fukuda. "Detoxification of Industrial Asbestos Waste by Low Temperature Heating in a Vacuum." Journal of the Ceramic Society of Japan, vol. 116, no. 2, pp. 242-246, Feb. 2008.

[22]. A. F. Gualtieriet, S. Pollastri. N. B. Gaandolfi, F. Ronchetti, C. Albonico and A. Cavallo. "Determination of The Concentration of Asbestos Minerals in Highly Contaminated Mine Tailings: An Example from Abandoned Mine Waste of Crètaz and Èmarese (Valle d'Aosta, Italy).” American Mineralogist, vol. 99, pp. 1233-1247, 2014.

[23]. H. W. Dunn and J. H. Stewart, Jr. "Determination of Chrysotile Asbestos in Building Materials by X-Ray Diffractometry." Analytical Chemistry, vol. 54, no. 7, pp. 1122-1125, Jun. 1982.

[24]. M. Taylor. "Methods for the Quantitative Determination of Asbestos and Quartz in Bulk Samples Using X-ray Diffraction.” Analyst, vol. 103, no. 1, pp. 1009-1020, Jan. 1978.

[25]. A. Ramelan. "KomunikasiPribadi”, November 17, 2016. 